\title{
Pengaruh jumlah pipa udara pada reaktor pembakaran pirolisis terhadap hasil arang dan asap cair
}

\author{
Fajar Khusaini ${ }^{1}$, Ridwan $^{2}$, Kemas Ridhuan ${ }^{3 *}$, Dwi Irawan ${ }^{4}$ \\ ${ }^{1}$ Prodi Teknik Mesin, Fakultas Teknik, Universitas Muhammadiyah Metro \\ JI. Ki Hajar Dewantara 15 A Kota Metro, Lampung, Indonesia \\ 2,3Jurusan Teknik Mesin, Fakultas Teknik, Universitas Muhammadiyah Metro \\ JI. Ki Hajar Dewantara 15 A Kota Metro, Lampung, Indonesia \\ ${ }^{*}$ Corresponding author: kmsridhuan69@gmail.com
}

\begin{abstract}
Pyrolysis temperature is very influential on the results of charcoal and liquid smoke can also be influenced by the amount of air that exists and the amount of air can be regulated by the number of air pipes. The purpose of this study was to determine the effect of variations in the number of air pipes 1, 3, 5 in the pyrolysis combustion reactor on the temperature and combustion time and the results of charcoal and liquid smoke. The research method is designing, manufacturing and testing a pyrolysis device with variations of 1, 3, 5 air pipes in a 1 inch diameter reactor, $8 \mathrm{~kg}$ corn cobs raw material, using a straight type condenser and $40 \mathrm{ml} / \mathrm{sec}$ cond flowing water. From the results of the research, variations in air pipes affect the temperature and time of combustion as well as the results of charcoal and liquid smoke. The highest temperature of the reactor occurred at pipe 5 variation, which is $485^{\circ} \mathrm{Cfor} 120$ minutes and the lowest temperature in pipe 1 was $353^{\circ} \mathrm{C}$ for 185 minutes. Variations in air pipes also greatly affect the yield of charcoal and liquid smoke. The yield of liquid smoke with the highest quantity in the variation of pipe 5 is $0.5 \mathrm{~kg}$ and the result of the least liquid smoke in the variation of pipe 1 as much as $0.32 \mathrm{~kg}$. For the highest charcoal yield in the variation of pipe 1 weighing $4 \mathrm{~kg}$ and for the least charcoal yield, namely in the variation of pipe 5 weighing 3.2 $\mathrm{kg}$.
\end{abstract}

Keywords: Air pipe, combustion, pyrolysis, charcoal, liquid smoke

\begin{abstract}
Abstrak
Temperatur pirolisis sangat berpengaruh terhadap hasil arang dan asap cair juga dapat dipengaruhi oleh jumlah udara yang ada dan banyaknya udara dapat diatur dengan jumlah pipa udara. Tujuan dari penelitian ini untuk mengetahui pengaruh variasi jumlah pipa udara 1, 3, 5 di dalam reaktor pembakaran pirolisis terhadap temperatur dan waktu pembakaran serta hasil arang dan asap cair. Metode penelitian yaitu merancang, membuat, serta menguji alat pirolisis dengan variasi pipa udara 1,3,5 di dalam reaktor berdiameter 1 inch, bahan baku tongkol jagung seberat $8 \mathrm{~kg}$, menggunakan kondensor tipe lurus dan debit air mengalir $40 \mathrm{ml} / \mathrm{detik}$. Dari hasil penelitian, variasi pipa udara berpengaruh terhadap temperatur dan waktu pembakaran serta hasil arang dan asap cair. Temperatur tertinggi reaktor terjadi pada variasi pipa 5 yaitu $485^{\circ} \mathrm{C}$ selama 120 menit dan temperatur terendah pada pipa 1 yaitu $353^{\circ} \mathrm{C}$ selama 185 menit. Variasi pipa udara juga sangat berpengaruh terhadap hasil arang dan asap cair. Hasil asap cair dengan kuantitas tebanyak pada variasi pipa 5 yaitu $0,5 \mathrm{~kg}$ dan hasil asap cair paling sedikit pada variasi pipa 1 sebanyak $0,32 \mathrm{~kg}$. Untuk hasil arang terbanyak pada variasi pipa 1 seberat $4 \mathrm{~kg}$ dan untuk hasil arang paling sedikit yaitu pada variasi pipa 5 seberat 3,2 kg.
\end{abstract}

Kata kunci: Pipa udara, pembakaran, pirolisis, arang, asap cair 


\section{Pendahuluan}

Biomassa merupakan salah satu sumber energi yang bersumber pada bahan biologis pada organisme yang belum lama mati. Selain digunakan untuk tujuan primer serat, bahan pangan, pakan ternak, minyak nabati, biomassa juga digunakan sebagai sumber energi (bahan bakar). Biomassa yang bersumber dari kayu antara lain: limbah penggergajian kayu, limbah plywood dan limbah logging. Selain ketersediaannya cukup banyak di Indonesia, karena Indonesia memiliki hutan tropis yang luas sehingga biomassa kayu banyak dimanfaatkan oleh masyarakat. Selain itu biomassa kayu juga cenderung tidak menyebabkan dampak negatif pada lingkungan. Salah satu pemanfatan biomassa yaitu dengan cara proses pirolisis.

Pirolisis adalah proses dekomposisi suatu bahan pada suhu tinggi tanpa adanya udara atau dengan udara terbataspirolisis biomassa umumnya berlangsung pada rentang suhu $300{ }^{\circ} \mathrm{C}$ sampai dengan $600{ }^{\circ} \mathrm{C}$. Namun keadaan ini sangat bergantung pada bahan baku dan cara pembuatannya. Suhu pirolisis untuk mereduksi biomassa dicapai secara optimal pada $300^{\circ} \mathrm{C}$ [1].

Beberapa faktor yang

mempengaruhi proses pirolisis yaitu kadar air, ukuran partikel, temperatur, waktu, bahan, dan tipe pirolisis. Hasil pirolisis berupa tiga jenis produk yaitu padatan (charcoall arang), gas (fuel gas) dan cairan (bio-oil) [2]. Proses pirolisis ini mengakibatkan terjadinya penguraian senyawa organik yang menyusun struktur bahan membentuk alkohol, tar, dan hidrokarbon, serta uap-uap asam asetat [3].

Penurunan berat molekul terjadi saat proses pirolisis sehingga dari penurunan tersebut menyebabkan polimer akan berubah menjadi monomer. Setiap biomassa memiliki karakteristik dan komposisi yang bebeda-beda tergantung dari jenis dan bentuknya. Seperti biomassa jenis kayu dengan tekstur keras, panjang, dan sedikit air. Kemudian kulit durian dengan bijian besar, lunak, kandungan air tinggi. Pada pembakaran pirolisis akan menghasilkan produk asap cair yang berbeda pula [4].

Pada proses pembakaran biomassa sebagai bahan bakar, jenis dan ukuran biomassa merupakan suatu hal yang sangat penting. Hal itu dikarenakan setiap biomassa memiliki cepat bakar yang berbeda. Hasil maksimum bio-oil $(47,3 \%)$ dapat diperoleh dan berkerja pada tingkat menengah untuk suhu operasi $\left(500^{\circ} \mathrm{C}\right)$. Suhu merupakan faktor yang paling penting, memiliki efek positif yang signifikan terhadap produk hasil bio-oil. Semakin tinggi suhu pirolisis yang diberikan maka produk padatan atau arang yang dihasilkan akan semakin sedikit [5].

Rizky pada tahun 2019 dalam penelitiannya variasi jumlah lubang udara yang diterapkan 20, lubang udara 30 , dan lubang udara 40 serta variasi kecepatan aliran udara primer memberikan pengaruh pada kinerja reaktor, semakin banyak jumlah lubang maka semakin besar nilai laju kalor, efisiensi termal dan laju konsumsi bahan bakar. Variasi kecepatan aliran udara yang diterapkan memberikan pengaruh pada kinerja kompor gasifikasi. Rata-rata ditiap variasi jumlah lubang udara, semakin tinggi kecepatan aliran udara yang diberikan maka semakin besar nilai laju kalor, efisiensi termal dan laju konsumsi bahan bakar [6].

Proses pembakaran biomassa dengan menambahkan jumlah pipa udara di dalam reaktor merupakan metode pembakaran dengan memanaskan biomassa melalui pipa udara di dalam reaktor sehingga udara panas yang berasal dari burner pembakaran masuk melalui pipa dan membakar biomassa. Pembakaran dengan metode ini dimaksudkan untuk lebih optimalnya panas dan suplai udara yang tercukupi pada reaktor, sehingga proses pemanasan berlangsung merata dan diharapkan mempersingkat waktu pembakaran bahan baku. Keuntungan dari proses ini adalah proses pembakaran dapat berlangsung secara cepat karena suplai oksigen dapat masuk melalui pipa udara sesuai dengan kebutuhan pembakaran pirolisis. dengan variasi jumlah pipa udara 
yaitu 1, 3, 5. Dari perbandingan jumlah pipa tersebut sehingga akan didapat banyaknya asap cair dan arang yang optimal. Kemudian asap dari pembakaran di dalam reaktor akan masuk pada proses kondensasi dari gas yang terbentuk, akan berubah wujud ke bentuk cairan. Asap cair adalah bahan cairan yang berwarna hitam yang berasal dari biomassa seperti kayu, kulit kayu dan biomassa lainnya seperti dari limbah kehutanan melalui proses pirolisis. Asap cair biasa digunakan sebagai bahan pengawet ikan, tahu, bakso, atau daging. Keuntungan penggunaan asap cair sebagai bahan pengawet adalah mampu menjaga kadar protein dan lemak yang terkandung dalam produk tersebut. Selain berfungsi sebagai pengawet makanan, asap cair biasa digunakan sebagai bahan baku disenfektan, kosmetik, hingga penyubur tanah dan pupuk. Produk lainnya yang dapat dihasilkan dari proses pirolisis berupa bioarang. Bio-arang dihasilkan dari pembakaran direaktor memiliki kualitas nilai kalor yang lebih baik. Dengan pengolahan biomassa tersebut menjadi bioarang pirolisis dapat meningkatkan nilai jual produk tersebut menjadi lebih baik [7].

\section{Tinjauan Pustaka}

\section{Biomassa}

Biomassa diartikan sebagai material tanaman, tumbuh-tumbuhan, atau sisa hasil pertanian yang digunakan sebagai bahan bakar atau sumber bahan bakar. Secara umum sumber-sumber biomassa yang tersedia di Indonesia antara lain, tongkol, jerami, tempurung kelapa, cangkang kelapa sawit dan lain sebagainya. Material kayu seperti kayu atau kulit kayu hasil logging, serbuk gergaji.

Sebagai bahan bakar, biomassa perlu dilakukan pengolahan terlebih dahulu agar dapat lebih mudah dipergunakan yang dikenal sebagai konversi biomassa.

\section{Pirolisis}

Pirolisis berasal dari kata Pyro (fire/api) dan Lyo (loosening/pelepasan proses dekomposisi termal dari suatu bahan organik. Pirolisis adalah proses konversi dari suatu bahan organik pada suhu tinggi dan terurai menjadi ikatan molekul yang lebih kecil. Teknologi ini adalah pembakaran yang tanpa melibatkan oksigen (O2) dalam proses pembakarannya. Pirolisis telah dikenal sejak ratusan tahun yang lalu untuk membuat arang dari sisa tumbuhan, sekitar pada abad ke-18 pirolisis dilakukan untuk menganalisis komponen penyusun biomassa [8].

\section{Reaktor Pirolisis}

Reaktor dengan penambahan jumlah pipa udara di dalam ruang pembakaran rmerupakan metode pembakaran dengan memanaskan biomassa melalui pipa udara di dalam reaktor sehingga uap panas yang berasal dari burner pembakaran masuk melalui pipa dan membakar biomassa. Pembakaran dengan reaktor jenis ini dimaksudkan untuk lebih optimalnya panas dan suplai udara yang tercukupi pada reaktor, sehingga proses pemanasan berlangsung merata dan diharapkan mempersingkat waktu pembakaran bahan baku. Keuntungan dari reaktor ini adalah proses pembakaran dapat berlangsung secara cepat karena suplai oksigen dapat masuk melalui pipa udara sesuai dengan kebutuhan pembakaran pirolisis. dengan variasi jumlah pipa udara yaitu 1, 3, 5. Dari perbandingan jumlah pipa tersebut sehingga akan didapat banyaknya asap cair dan arang yang optimal.

\section{Arang}

Arang biomassa adalah produk yang diperoleh dari pembakaran tidak sempurna terhadap biomassa tersebut. Pembakaran tidak sempurna terhadap biomassa akan menyebabkan senyawa karbon kompleks tidak teroksidasi menjadi karbon dioksida, peristiwa tersebut disebut sebagai pirolisis . Pada saat pirolisis, energi panas mendorong terjadinya oksidasi sehingga sebagian besar molekul karbon yang kompleks terurai menjadi karbon atau arang. Makin rendah kadar abu, air, dan zat yang menguap maka makin tinggi pula kadar fixed carbonnya dan 
mutu arang tersebut juga akan semakin tinggi [9].

Pembakaran

Pembakaran pirolisis dapat menghasilkan produk utama yang berupa arang (char), asap cair (bio-oil) dan gas. Arang yang dihasilkan merupakan bahan bakar bernilai kalori yang tinggi ataupun digunakan sebagai karbon aktif.Asap cair yang dihasilkan dapat digunakan sebagai zat additive atau bahan pengawet makanan atau produk tertentu. Sedangkan gas yang terbentuk dapat dibakar secara langsung.

\section{Asap cair}

Salah satu cara untuk membuat asap cair adalah dengan mengkondensasikan asap hasil dari pembakaran tidak sempurna dari kayu. Selama pembakaran, komponen utama kayu yang berupa selulosa, hemiselulosa, dan lignin akan mengalami pirolisis. Asap cair diperoleh dengan teknis pirolisis, dimana senyawa-senyawa yang menguap secara simultan akan ditarik dari zona reaktor panas dan akan berkondensasi pada system pendingin. Ditambahkan bahwa selama proses kondensasi akan terbentuk kondensat asap kasar yang akan memisah menjadi tiga fasa, yaitu fase larut dalam air, fase tidak larut dalam air dan fase $\operatorname{tar}[10]$.

Asap cair mempunyai beberapa kelebihan yaitu : mudah diterapkan/praktis penggunaannya, flavor produk lebih seragam, dapat digunakan secara berulangulang, lebih efisien dalam penggunaan bahan pengasap, dapat diaplikasikan pada berbagai jenis bahan pangan, polusi lingkungan dapat diperkecil dan yang paling penting senyawa karsinogen yang terbentuk dapat dieliminasi[10]. Diketahui pula bahwa temperatur pembuatan asap merupakan faktor yang paling menentukan kualitas asap yang dihasilkan. Produk yang diberikan asap cair yang dihasilkan pada temperatur $400^{\circ} \mathrm{C}$ dinilai mempunyai kualitas organoleptik yang terbaik dibandingkan dengan asap cair yang dihasilkan pada temperatur pirolisis yang lebih tinggi.

\section{Metode Penelitian}

Metode yang digunakan dalam penelitian ini adalah dengan metode eskperimental dengan melakukan pembuatan dan pengujian burner oli dan air. Pengujian dilakukan dengan menjalankan atau menggunaan alat pirolisis dengan variasi pipa udara 1, 3, 5 di dalam reaktor.

Adapun tahapan penelitian dari proses pengujian Pirolisis dengan variasi pipa udara didalam reaktor terdiri dari beberapa tahap yaitu :

a. Pengeringan Bahan baku (Biomassa)

Setelah tongkol jagung sudah terkumpul proses selanjutnya adalah mengeringkan bahan baku di bawah sinar matahari sampai benar-benar kering yang bertujuan untuk mengurangi kadar air di dalam tongkol jagung tersebut.

b. Persiapan Alat Pirolisis

Mempersiapkan alat yang akan digunakan dalam penelitian seperti alat ukur termokopel, tabung reaktor yang sudah divariasi dengan pipa udara di dalamnya, dan kondensor pipa lurus.

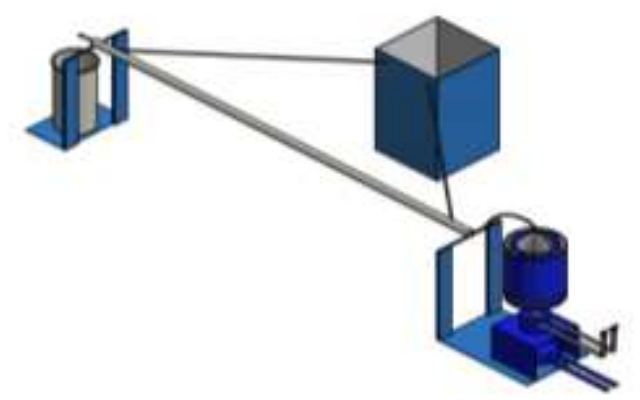

Gambar 1. Desain Alat Pirolisis

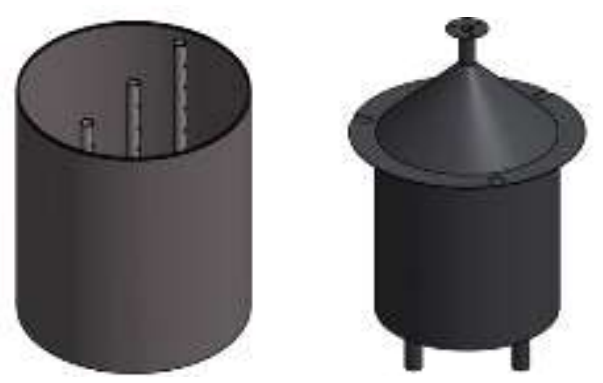

Gambar 2. Desain Reaktor Pirolisis

\section{c. Pengujian Pirolisis}

Dalam penelitian ini burner yang dipakai dalam proses pembakaran pirolisis 
yaitu burner oli dan air kemudian dihidupkan, setelah itu mengarahkan burner tesebut ke Reaktor pirolisis untuk membakar biomassa yang ada di reaktor. Data temperatur yang diukur dan waktunya dicatat. Setelah selesai, mencatat jumlah arang dan asap cair yang didapat. Kemudian, mlakukan cara yang sama untuk tiap jumlah pipa udara 1, 3 dan 5 .

Penelitian ini dilaksanakan di Laboratorium Teknik Mesin Universitas Muhammadiyah Metro.

\section{Hasil dan Pembahasan}

\section{Jumlah Pipa Udara didalam Reaktor Pembakaran Pirolisis Terhadap Temperatur dan Waktu yang Dihasilkan}

Berikut ini pengaruh dari variasi pipa udara didalam reaktor pirolisis serta menggunakan burner pembakaran oli dan air temperatur dan waktu pembakaran pirolisis terhadap hasil arang dan asap cair. Berikut pengaruh variasi pipa udara di dalam reaktor pirolisis terhadap temperatur dan waktu pembakaran pirolisis.

\section{Pengujian dengan variasi 1 pipa udara di dalam reaktor pirolisis dengan biomassa tongkol jagung $8 \mathrm{~kg}$.}

Pada gambar 3 Variasi 1 pipa udara didalam reaktor memiliki suhu tertinggi di dalam reaktor yaitu $353^{\circ} \mathrm{C}$ dan suhu tertinggi pada api burner pembakaran yaitu $1011^{\circ} \mathrm{C}$. Variasi 1 pipa udara juga sangat berpengaruh terhadap cepat atau lambatnya biomassa yang ada didalam reaktor terdekomposisi, dapat dilihat dari garfik bahwa temperatur pada reaktor pembakaran sangat kecil sehingga berpengaruh pada waktu pembakaran. Pengaruh penambahan variasi 1 pipa udara di dalam reaktor juga hanya menghasilkan suhu tertinggi di dalam reaktor yaitu sebesar $353^{\circ} \mathrm{C}$ hal itu dikarenakan suplai udara panas pada burner pembakaran hanya sedikit yang masuk melalui 1 pipa udara ke dalam reaktor pembakaran pirolisis sehingga memperlambat proses penguraian biomassa pada reaktor. Penurunan temperatur pada T1 diakibatkan oleh bahan bakar oli dan air yang sudah mulai habis sehingga api yang dihasilkan semakin kecil dan harus dilakukannya pengisian bahan bakar oli dan air. Selain itu penurunan pada T1 juga bisa diakibatkan oleh tersumbatnya pipa api pada burner yang yang disebabkan kerak asap yang menempel pada pipa sehingga perlu dilakukannya pembersihan agar api bisa menyala secara maksimal.

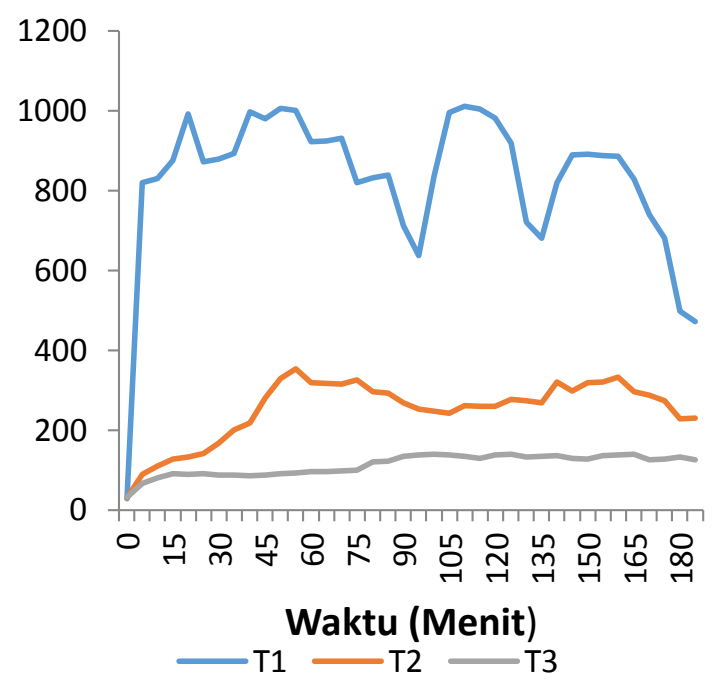

Gambar 3. Pengaruh variasi 1 pipa udara terhadap temperatur yang dihasilkan

Temperatur yang rendah pada reaktor juga mempengaruhi waktu pembakaran pada proses pirolisis. Pada variasi 1 pipa udara didalam reaktor membutuhkan waktu 30 menit sampai asap cair mulai menetes dan 185 menit sampai asap cair mulai berhenti menetes. Sehingga untuk proses pirolisis $8 \mathrm{~kg}$ tongkol jagung dengan variasi 1 pipa udara didalam reaktor memiliki waktu yaitu 185 menit sampai berhenti menetes

\section{Pengujian dengan variasi 3 pipa udara didalam reaktor pirolisis dengan biomassa tongkol jagung 8 kg.}

Pada gambar 4, variasi 3 pipa udara di dalam reaktor memiliki temepratur tertinggi pada api burner pembakaran sebesar $1005^{\circ} \mathrm{C}$ dan suhu tertingi di dalam reaktor sebesar $385^{\circ} \mathrm{C}$. Bisa dilihat pada grafik dimana penambahan pipa 3 sangat 
berpengaruh terhadap temperatur yang dihasilkan. Hal ini dikarenakan suplai udara panas yang masuk melalui lubang pada pipa udara lebih banyak dibandingkan dengan variasi 1 pipa. Pada gambar di bawah naik turunnya T1 secara drastis disebabkan oleh bahan bakar oli dan air pada burner sudah mulai habis sehingga api yang dihasilkan semakin mengecil sehingga harus dilakukannya pengisian bahan bakar oli dan air agar temperatur pada api burner kembali naik. Penyumbatan pada pipa saluran api juga mempengaruhi nyala api sehingga harus selalu dibersihkan agar api menyala secara maksimal

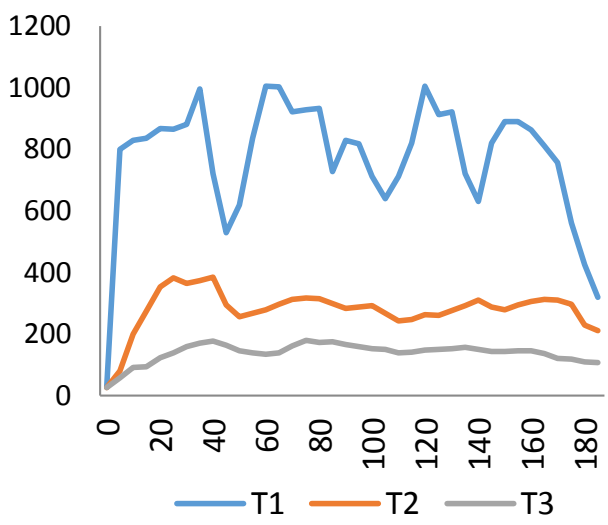

Gambar 4. Pengaruh variasi 3 pipa udara terhadap temperatur yang dihasilkan

Dengan adanya penambahan pipa udara didalam reaktor yang awalnya hanya berjumlah 1 buah pipa dan kini ditambah 3 pipa membuat proses pembakaran pirolisis hanya membutuhkan waktu 15 menit sampai asap cair mulai menetes dikarenakan suplai udara panas yang lebih banyak dibandingkan dengan 1 pipa udara sehingga biomassa lebih cepat terdekomposisi menjadi asap. Pada proses pirolisis dengan variasi 3 pipa udara didalam reaktor membutuhkan waktu 15 menit sampai menetes dan 185 menit sampai berhenti menetes .

\section{Pengujian dengan variasi 5 pipa udara didalam reaktor pirolisis dengan biomassa tongkol jagung $8 \mathrm{~kg}$.}

Pada gambar 5. Variasi 5 pipa udara didalam reaktor memiliki suhu tertinggi pada api burner pembakaran sebesar $1025^{\circ} \mathrm{C}$ dan suhu tertingi di dalam reaktor sebesar $485^{\circ} \mathrm{C}$. Penambahan variasi 5 pipa sangat berpengaruh terhadap temperatur yang dihasilkan hal ini terjadi karena suplai udara panas yang masuk lebih banyak dibandingkan pipa 3 dan 1 . Temperatur di dalam reaktor yang tinggi juga berpengaruh terhadap waktu proses pembakaran. Naik turunnya temperatur pada T1 diakibatkan oleh kondisi bahan bakar oli dan air pada burner akan segera habis sehingga nyala api yang dihasilkan semakin kecil.

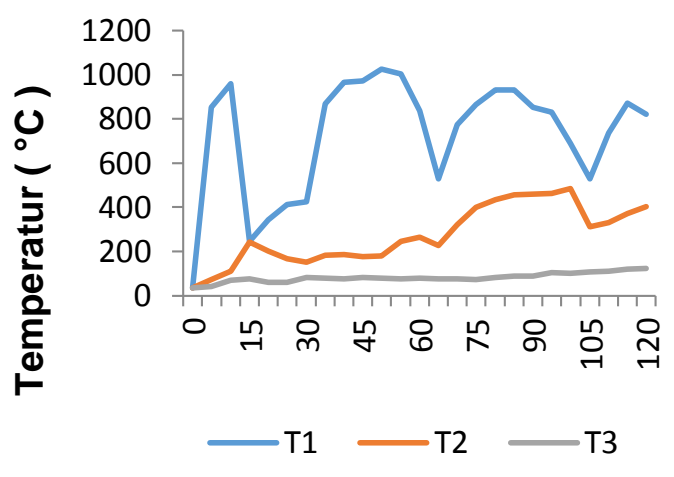

Gambar 5. Pengaruh variasi 5 pipa udara terhadap temperatur yang dihasilkan

Proses pirolisis dengan variasi 5 pipa udara di dalam reaktor hanya membutuhkan waktu 15 menit sampai asap cair mulai menetes. Hal ini bisa dilihat pada grafik bahwa temperatur variasi 5 pipa udara di dalam reaktor lebih tinggi dibandingkan variasi pipa 1 dan 3 . Pada variasi 5 pipa udara di dalam reaktor membutuhkan waktu 15 menit asap cair mulai menetes dan 120 menit asap cair berhenti menetes.

Pada gambar 6, dapat dilihat perbedaan temperatur di dalam reaktor untuk setiap variasi pipa $1,3,5$ di dalam reaktor. Pada gambar 26. Dapat dilihat bahwa temperatur tertinggi pada reaktor pirolisis yaitu jenis variasi 5 pipa udara dengan temperatur mencapai $485^{\circ} \mathrm{C}$ dan membutuhkan waktu 120 menit sampai asap cair berhenti menetes. 


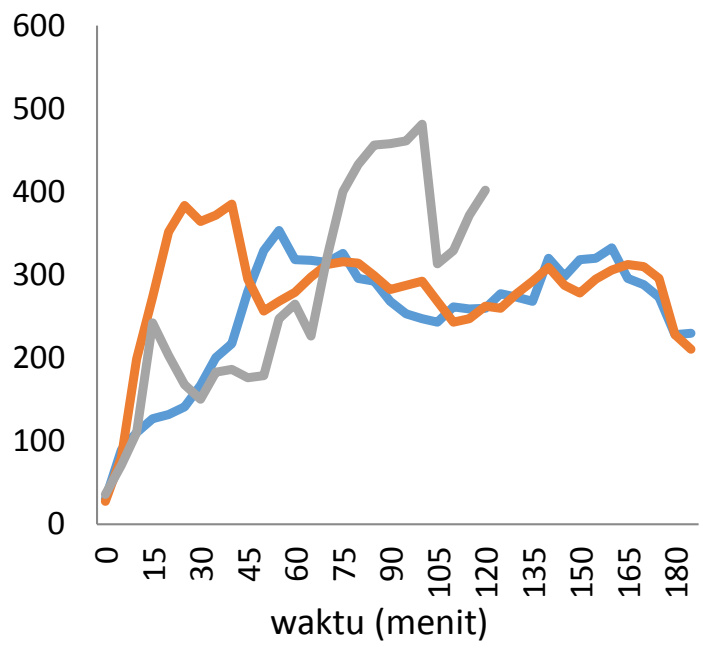

Gambar 6. Perbedaan temperatur pada reaktor pirolisis masing masing variasi

Untuk pipa 3 menghasilkan temperatur tertinggi mencapai $385^{\circ} \mathrm{C}$ dan membutuhkan waktu 185 menit sampai asap cair berhenti menetes dan untuk var pipa 1 menghasilkan temperatur tertinggi mencapai $353^{\circ} \mathrm{C}$ dan membutuhkan 185 menit sampai asap cair berhenti menetes. Pada variasi pipa 5 mendapatkan temperatur tertinggi pada reaktor dibandingkan dengan variasi pipa 1 dan 3 dikarenakan jumlah pipa dan lubang yang lebih banyak sehingga udara panas pada burner pembakaran dapat diserap dengan baik untuk mendekomposisi biomassa yang berada di dalam reaktor. Perbedaan temperatur pada masing masing pipa di dalam reaktor juga memberikan pengaruh pada lama waktu proses pembakaran, semakin banyak jumlah pipa dan lubang pada reaktor maka proses pembakaran pirolisis akan semakin cepat. Pada gambar di atas naik turunnya temperatur di dalam reaktor diakibatkan oleh api burner pembakaran yang kurang stabil sehingga mempengaruhi temperatur yang ada di dalam reaktor. Kurang stabilnya api pada burner pembakaran juga mengakibatkan penyerapan udara panas pada masing masing pipa kurang efektif sehingga menghasilkan pirolisis slow yaitu dengan temperatur berkisar $300^{\circ} \mathrm{C}-485^{\circ} \mathrm{C}$.

\section{Perbandingan Waktu Pirolisis}

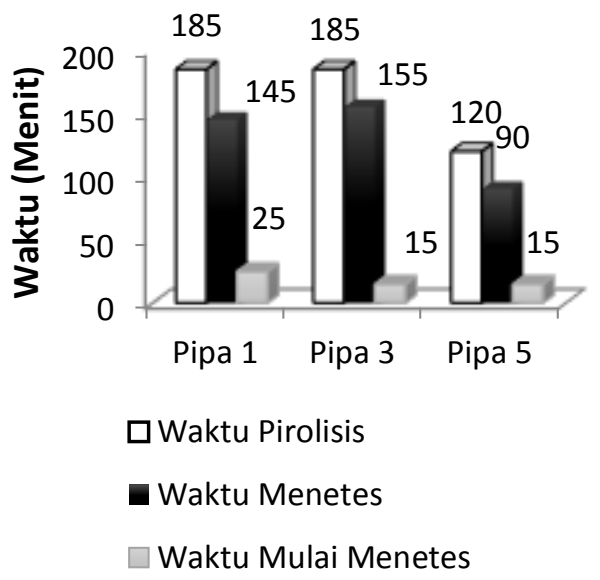

Gambar 7. Grafik Perbandingan Waktu Menetes Setiap Variasi

Pada gambar 7 di atas dapat dilihat bahwa temperatur pada di setiap variasi pipa 1, 3, 5 memiliki pengaruh terhadap waktu pembakaran pirolisis. Pada variasi pipa 1 dengan temperatur tertinggi di dalam reaktor $353{ }^{\circ} \mathrm{C}$ menghasilkan waktu pembakaran yaitu 185 menit dan asap cair mulai menetes pada menit ke 25 dan menetes selama 145 menit. Pada variasi pipa 3 dengan temperatur tertinggi di dalam reaktor $385^{\circ} \mathrm{C}$ menghasilkan waktu pembakaran yaitu 185 menit dan asap cair mulai menetes pada menit ke 15 dan menetes selama 155 menit . Pada pipa 3 asap cair mulai menetes lebih cepat dibandingkan dengan pipa 1 dikarenakan suplai udara panas yang masuk melalui pipa lebih banyak sehingga lebih cepat menguraikan biomassa. Pada variasi pipa 5 dengan temperatur tertinggi di dalam reaktor $485^{\circ} \mathrm{C}$ menghasilkan waktu pembakaran yaitu 120 menit dan asap cair mulai menetes pada menit ke 15 dan menetes selama 90 menit. Waktu pembakaran pada pipa 5 lebih cepat dibandingkan dengan pipa 1 dan 3 dikarenakan temperatur yang dihasilkan lebih tinggi dibandingkan dengan pipa 1 dan 3 sehingga biomasaa lebih cepat terurai menjadi asap dan menghasilkan asap cair. 


\section{Pengaruh Jumlah Pipa Udara didalam Reaktor Pembakaran Pirolisis Terhadap Presentase Hasil Arang dan Asap Cair}

\section{Hasil arang dan asap cair}

Hasil pirolisis berupa arang dan asap cair berbanding terbalik. Semakin banyak asap cair yang dihasilkan maka semakin sedikit arang yang dihasilkan. Dari variasi 5 pipa udara di dalam reaktor dengan biomassa tongkol jagung seberat $8 \mathrm{~kg}$ mendapatkan $0,5 \mathrm{~kg}$ asap cair, $0,4 \mathrm{~kg}$ menggunakan 3 variasi pipa udara serta 0,32 $\mathrm{kg}$ menggunakan 1 variasi pipa udara didalam reaktor. Variasi 5 pipa udara mendapatkan arang $3,4 \mathrm{~kg}$, variasi 3 pipa mendapatkan $3,8 \mathrm{~kg}$ arang, dan 1 variasi pipa mendapatkan $4 \mathrm{~kg}$ arang. Hasil arang dan asap cair sangat dipengaruhi oleh temperatur yang ada didalam reaktor. Pada proses pembakaran dengan variasi pipa udara 1, 3, 5 menghasilkan tipe pirolisis slow karena hanya menghasilkan temperatur $200^{\circ} \mathrm{C}-400^{\circ} \mathrm{C}$ di dalam reaktor sehingga produk yang dihasilkan lebih banyak arang daripada asap cair. Hal ini dikarenakan semakin tingginya temperatur di dalam reaktor akan mempengaruhi hasil arang dan asap cair yang didapat. Sesuai dengan pernyataan Lin dan Kuo, (2012) Pirolisis slow yaitu proses pirolisis yang membutuhkan waktu yang lebih lambat dan menggunakan temperatur reaksi di dalam reaktor yang lebih rendah yaitu sekitar $400^{\circ} \mathrm{C}$ sehingga produk yang dihasilkan lebih banyak arang dibandingkan dengan asap cair. Dari hasil pengujian yang telah dilakukan setiap variasi pipa udara memiliki karakteristik yang tidak jauh berbeda di setiap asap cair yang dihasilkan. Asap cair grade 3 yang dihasilkan dari variasi 1 pipa udara memiliki kandungan $\mathrm{pH}$ yang cukup besar yaitu 3,43 . Sedangkan untuk variasi 3 pipa udara memiliki kandungan $\mathrm{pH} 3,31$, kandungan. Untuk variasi 5 pipa udara memiliki kandungan $\mathrm{pH}$ terendah yaitu 3,11.

Sesuai dengan penelitian yang dilakukan oleh Maulina dan Sari (2017) bahwa peningkatan temeperatur akan menyebabkan $\mathrm{pH}$ asap cair yang dihasilkan semakin rendah, hal ini disebabkan semakin tingginya temperatur pirolisis, konversi selulosa, hemiselulosa dan lignin yang ada dalam bahan baku menjadi lebih besar sehingga menyebabkan nilai $\mathrm{pH}$ semakin kecil [3].

Dari data tersebut dapat disimpulkan bahwa variasi 5 pipa udara merupakan variasi yang lebih banyak menghasilkan asap cair pada proses pirolisis dibandingkan variasi lainnya, dikarenakan panas api dari burner pembakaran lebih cepat masuk dan menyebar keseluruh bagian reaktor sehingga dapat menghasilkan temperatur yang tinggi dibandingkan variasi 1 dan 3 sehingga mempercepat proses dekomposisi pada biomassa dan memproduksi asap dan dikondensasikan menjadi asap.cair.

\section{Presentase hasil arang dan asap cair}

Nilai presentase arang dari variasi 1 pipa adalah $50 \%$ dan untuk presentase arang variasi 3 pipa adalah $47,50 \%$ dan untuk presentase arang variasi 5 pipa udara adalah $42,50 \%$ Sedangkan untuk presentase asap cair dari variasi 1 pipa adalah $4 \%$, presentase asap cair variasi 3 pipa adalah 5\% dan variasi 5 pipa adalah $6,25 \%$. dapat disimpulkan bahwa perbedaan hasil arang dan asap cair pada setiap variasi dikarenakan suplai udara panas yang masuk melalui pipa udara tersebut berbeda beda sehingga mempengaruhi proses pirolisis dan lama waktu terhadap hasil dan asap cair yang dihasilkan. Presentase arang lebih besar dibandingkan dengan presentase asap cair dikarenakan proses pirolisis yang dihasilkan dari variasi pipa $1,3,5$ yaitu pirolisis slow dikarenakan temperatur tertinggi di dalam reaktor hanya mencapai $485^{\circ} \mathrm{C}$ sehingga lebih banyak menghasilkan arang dibandingkan dengan asap cair.

Dibandingkan dengan penelitian Ridhuan (2019) dari hasil penelitian presentase asap cair biomassa kayu jengkol seberat $30 \mathrm{~kg}$ pada pembakaran langsung menghasilkan sebanyak $148 \mathrm{ml}$ atau 0,31\% dan untuk pembakaran biomassa menghasilkan sebanyak $172 \mathrm{ml}$ atau $0,43 \%$ dan pembakaran LPG menghasilkan 
sebanyak $244 \mathrm{ml}$ atau $0,72 \%$. Sedangkan presentase arang dari pembakaran langsung sebesar $27,66 \%$ atau $8,3 \mathrm{~kg}$ sedangkan pembakaran biomasa menghasilkan sebesar $14,33 \%$ atau $4,3 \mathrm{~kg}$ dan pembakaran LPG menghasilkan sebesar $30 \%$ atau $9 \mathrm{~kg}$ [7].

\section{Kesimpulan}

Dari penelitian yang telah dilakukan dimulai dari pengujian, pengambilan data, dan analisa data dapat disimpulkan bahwa variasi pipa udara $1,3,5$ di dalam reaktor pirolisis sangat berpengaruh pada temperatur di dalam reaktor serta waktu pada saat prores pembakaran. Variasi pipa terbaik terjadi pada variasi pipa 5 menghasilkan temperatur $485{ }^{\circ} \mathrm{C}$ di dalam reaktor dan memiliki waktu reaksi yaitu 120 menit sampai asap cair berhenti menetes. Variasi pipa 1 menghasilkan temperatur terkecil yaitu $353{ }^{\circ} \mathrm{C}$ di dalam reaktor dan membutuhkan waktu reaksi 185 menit sampai asap cair berhenti menetes. Jadi semakin banyak pipa udara maka semakin tinggi temperatur di dalam reaktor serta mempersingkat waktu proses pembakaran sampai asap cair berhenti menetes.

Hasil pirolisis berupa arang dan asap cair berbanding terbalik, semakin banyak asap cair yang dihasilkan maka semakin sedikit arang yang didapat Variasi pipa udara 1, 3, 5 sangat berpengaruh terhadap hasil arang dan asap cair yang dihasilkan. Untuk hasil asap cair dengan jumlah terbanyak yaitu pada variasi pipa 5 dengan hasil $0,5 \mathrm{~kg}$ dan $3,4 \mathrm{~kg}$ arang dari bahan baku $8 \mathrm{~kg}$ tongkol jagung. Sehingga nilai presentase asap cair pirolisis menggunakan variasi 5 pipa udara sebesar $6,25 \%$.

\section{Referensi}

[1] Basu, P. 2010. Biomass Gasification And Pyrolysis Practical Design And Theory. Oxford: Elsevier Inc.

[2] Wijayanti, Widya. Nur, Mega Sasongko. Dkk., 2013, Metode Pirolisis Untuk Penanganan Sampah Perkotaan Sebagai Penghasil Bahan Bakar Alternatif, Jurnal Rekayasa
Mesin, Vol.4, No.2, ISSN 0216468X, Hlm. 85-92

[3] Seri Maulina, Feni Sari Putri. 2017. Pengaruh Suhu, Waktu, Dan Kadar Air Bahan Baku Terhadap Pirolisis Serbuk Pelepah Kelapa Sawit . Jurnal Teknik Kimia USU, Vol. 6, No. 2 . Departemen Teknik Kimia, Fakultas Teknik, Universitas Sumatera Utara.

[4] Guillen, M.D., Dkk. 2001. Carbohydrate And Nitrogenated Coumpounds In Liquid Smoke Flavoring. J Agric Food Chem 49: 2395-2403

[5] Ratnawati,. Hartanto, S., 2010. Pengaruh Suhu Pirolisis Cangkang Sawit Terhadap Kuantitas Dan Kualitas Asap Cair. Jurnal Akreditasi LIPI, 2010, 12 (1) : 7-11

[6] Rizky , Dkk 2019. Pengaruh Jumlah Lubang Udara Pada Tungku Pembakaran Serta Variasi Kecepatan Aliran Udara Terhadap Kinerja Kompor Gasifikasi Dengan Bahan Bakar Pelet Kayu Jati e-Proceeding of Engineering : Vol.6, No.2 Agustus 2019 | Page 5225

[7] Ridhuan, K. et al 2019 Pengaruh Jenis Biomassa Pada Pembakaran Pirolisis Terhadap Karakteristik Dan Efisiensi Bioarang - Asap Cair Yang Dihasilkan

[8] Nindita, D. 2012. Sintesis Bioaspal Dari Serbuk Gergaji Kayu Albasia Dengan Metode Pirolisis. [Skripsi]. Depok. Program Studi Ekstensi Teknik Kimia. Fakultas Teknik. Universitas Indonesia.

[9] Nicolas Tumbel, 2019. Proses Pengolahan Arang Tempurung Kelapa Menggunakan Tungku Pembakaran Termodifikasi Coconut Shell Charcoal Processing Process Using A Modified Combustion Furnace Jurnal Penelitian Teknologi Industri Vol. 11 No. 2 Desember 2019 : h 83-92

[10] Simon R, Calle B, Palme S, Meler D, Anklam E. 2005. Composition And Analysis Of Liquid Smoke Flavouring Primary Products. J. Food Sci. 28: 871-882 Hlm. 85-92. 